\title{
Dietary habits in women with recurrent idiopathic calcium nephrolithiasis
}

\author{
Tiziana Meschi ${ }^{1}$, Antonio Nouvenne ${ }^{1 *}$, Andrea Ticinesi ${ }^{1}$, Beatrice Prati ${ }^{1}$, Angela Guerra', Franca Allegri ${ }^{1}$, \\ Federica Pigna ${ }^{1}$, Laura Soldati ${ }^{2}$, Giuseppe Vezzoli ${ }^{3}$, Giovanni Gambaro ${ }^{4}$, Fulvio Lauretani ${ }^{5}$, Marcello Maggio ${ }^{6}$ and \\ Loris Borghi ${ }^{1}$
}

\begin{abstract}
Background: Nutrition has been widely recognized to influence the risk of kidney stone formation. Therefore the aim of our study was to assess: a) whether usual diet of women with idiopathic calcium nephrolithiasis (ICN) living in Parma (Northern-Italy) is different compared to healthy controls, b) how their diet differs from Italian National guidelines and c) whether it is related to nephrolithiasis clinical course.
\end{abstract}

Methods: 143 women with recurrent ICN (mean age $43 \pm 13$ ys) and 170 healthy women (mean age $42 \pm 11$ ys) were enrolled. All women completed a food frequency questionnaire for the last 60-days and a 3-day dietary diary analysed with a dedicated software.

Results: Stone formers showed a higher consumption of sausages, ham, meat and sweets than healthy controls ( $43.1 \%$ vs $11.1 \%, 29.4 \%$ vs $13.9 \%, 21.6 \%$ vs $4.2 \%, 66.7 \%$ vs $18.1 \%, p<0.001)$. The 3 -day diary analysis showed an intake of calories, carbohydrates, lipids and non-discretionary sodium about 10\% higher than healthy controls $(p<$ $0.001)$. Finally, after dividing the population into 3 age groups ( $\leq 30,31-40,>40$ years), the differences described above were amplified in the class $\leq 30$ years, where nephrolithiasis presented a more serious course (shorter recurrence interval, greater stone-rate). In this age group the intake of fruit and vegetables was notably lower than guideline recommendations.

Conclusions: We conclude that the usual diet of women with recurrent ICN is different from controls and characterized by low intake of fruits and vegetables and higher consumption of simple sugars and foods with high protein and salt content. This dietary imbalance could play a role in the ICN pathogenesis, especially in younger women.

This work was financed by grants from Italian Ministry of University and Research as part of a larger project about the prevention of kidney stones (PRIN 2005063822) and by Fondazione per la Ricerca Scientifica Termale (FoRST). No potential conflict of interest relevant to this paper was reported.

Keywords: Idiopathic calcium nephrolithiasis, Diet, Kidney stones, Food frequency

\section{Background}

Several evidences in medical literature point out that inadequate nutrition has a direct effect on urinary stone risk factors and on the development of kidney stones [1-6]. A high animal protein diet increases urinary calcium, uric acid, oxalate, and phosphorus and decreases urinary citrate and $\mathrm{pH}$, as an effect of a higher intake of

\footnotetext{
* Correspondence: antonio.nouvenne@alice.it

'Department of Clinical Sciences, University of Parma, Via A. Gramsci 14,

43126 Parma, Italy Full list of author information is available at the end of the article
}

purine and phosphorus and urinary acidification [7-9]. Similar lithogenic changes have been reported with high carbohydrate and fat intake [10-12]. Even salt intake, which is generally much higher than recommended in industrialized countries, represents a powerful factor that increases calciuria and lithogenic risk, in synergy with animal proteins [13-15]. On the other hand, a low calcium intake was formerly thought to be protective against the onset of kidney stones, but nowadays is considered a risk factor, since it promotes the intestinal absorption of oxalate and encourages the onset of bad
Ciomed Central 
dietary habits, such as a high animal protein intake [16-18]. Furthermore, a low consumption of fruit and vegetables, leading to an inadequate intake of anti-lithogenic factors such as potassium, magnesium and citrate, is considered a risk factor for kidney stone too, although there are some fruits (such as figs, prunes and raspberries) and vegetables (such as beets, spinach and tomatoes) which are the main dietary sources of oxalate [18-20]. As a matter of fact, the oxalate excretion is poorly related to the dietary intake [21].

A low fluid intake is a heavy risk factor for kidney stone formation, leading to a low urine volume and thus higher urinary concentration of lithogenic substances $[22,23]$. All kind of drink share this beneficial effect, except few juices (such as apple juice and grapefruit juice), cola and some sport drinks, for their elevated content of oxalate and carbohydrates, such as fructose [24-26].

Although the relationship between diet and kidney stones has been investigated by a large number of studies, results from studies comparing stone former and healthy control dietary habits are contradictory; moreover, whether these supposed differences are important in the development and the progression of the disease is unclear [27-34].

Therefore, in Parma area (Northern Italy), we analyzed the dietary habits of a group of women suffering from recurrent idiopathic calcium nephrolithiasis through two different survey instruments (three-day dietary diary and food frequency questionnaire), comparing them with a healthy control group. We chose to investigate only female subjects because the incidence of kidney stones is rising particularly in women, in a way that seems correlated to dietary changes that occurred in the last decades [18]. Our main purpose was to determine whether the dietary habits of adult female stone formers are significantly different than those of healthy women. Secondly, we aimed to assess whether the food intake of the two groups differ from recommendations of the Italian National Institute for Research on Foods and Nutrition (INRAN) [35]. Finally, we aimed to determine if diet is related to the clinical course of kidney stones in the study sample.

\section{Materials and methods}

At the Kidney Stone Clinic of the Clinical Science Department, University of Parma, we consecutively enrolled 143 normotensive women with recurrent idiopathic calcium nephrolithiasis (mean age $43 \pm 13$ years). A written informed consent was obtained. The study was performed in compliance with Helsinki declaration. Every patients had previously at least one stone expelled and analyzed, with a stone composition of calcium-oxalate $>80 \%$. No patient had significant co-morbidity (ie, primary hyperparathyroidism, primary hyperoxaluria, inflammatory bowel disease, renal tubular acidosis, sarcoidosis, sponge kidney, hyperthyroidism) or interfering drug therapy capable of modifying the risk of stone risk formation, including biphosphonates, vitamin D, thiazides, calcium supplements, estrogens, alkaline citrate and allopurinol. Patients were defined normotensive according to the European Society of Cardiology and Hypertension guidelines (systolic pressure $<129 \mathrm{mmHg}$, diastolic pressure $<84 \mathrm{mmHg}$ ) [36].

We also enrolled 170 healthy normotensive female volunteers (mean age $42 \pm 11$ years). For the enrolment of volunteers, different procedures have been used: cooperation with stone formers patients in order to find acquaintances or friends willing and able to take part in the study and targeted invitations to the population residing in Parma. No incentive was given to participants to be enrolled in the present study. The general characteristics of the study subjects are shown in Table 1. All patients have their medical history recorded in computed medical records. A program calculates stone severity through stone rate computation following the formula (total $\mathrm{n}$. of stones - n. of stone at $1^{\text {st }}$ episode/time between $1^{\text {st }}$ and last episode).

All women in the study, stone formers and controls, filled a dietary diary for three non-consecutive days, reporting all the food intake. This diary was subsequently discussed and interpreted in a visit with a dietician.

The diaries were afterwards analyzed by a specific software with a comprehensive database for a wide variety of macro- and micronutrients (Dietosystem, DS Medica, Milan). This software allows to determine the nutrient composition of every food eaten. We had

Table 1 Main characteristics of the women at baseline.

\begin{tabular}{cccc}
\hline & $\begin{array}{c}\text { STONE } \\
\text { FORMERS } \\
(\mathbf{N}=\mathbf{1 4 3})\end{array}$ & $\begin{array}{c}\text { CONTROLS } \\
(\mathbf{N}=\mathbf{1 7 0})\end{array}$ & $\mathbf{p}$ \\
\hline AGE $(\mathrm{yr})$ & $43 \pm 13$ & $42 \pm 11$ & 0.32 \\
\hline WEIGHT $(\mathrm{kg})$ & $64 \pm 12$ & $62 \pm 11$ & 0.32 \\
\hline HEIGHT $(\mathrm{cm})$ & $163 \pm 7$ & $163 \pm 7$ & 0.51 \\
\hline BMI $(\mathrm{Kg} / \mathrm{m})^{2}$ & $24,1 \pm 4,4$ & $23,5 \pm 3,9$ & 0.21 \\
\hline SYSTOLIC PRESSURE $(\mathrm{mmHg})$ & $118 \pm 6$ & $118 \pm 12$ & 0.11 \\
\hline DIASTOLIC PRESSURE $(\mathrm{mmHg})$ & $76 \pm 5$ & $74 \pm 8$ & 0.09 \\
\hline STONE RATE & $0,51 \pm 0,76$ & - & - \\
(number Of stones per patient per $_{\text {year) }}^{*}$ & & & \\
\hline AGE OF THE FIRST EPISODE $(\mathbf{y r})$ & $35,3 \pm 14,6$ & - & - \\
\hline INTERVAL BETWEEN & $7,1 \pm 9,6$ & - & - \\
1ST AND 2 & & & \\
\hline
\end{tabular}

- Data are shown as mean \pm standard deviation.

* Stone rate was calculated following the formula (total n. of stones - n. of stone at $1^{\text {st }}$ episode/time between $1^{\text {st }}$ and last episode). 
previously extended the software database in collaboration with the software developers, including recent data from national and international institutions' databases and from scientific papers. We particularly focused on those micronutrients which are notably involved in the pathogenesis of nephrolithiasis, such as sodium, potassium, calcium, oxalate, magnesium and phosphorus.

All stone formers and controls were also given by a dietician a validated food frequency questionnaire of the last 60 days (a facsimile of the form is shown in Additional file 1). This instrument allowed us to perform a further analysis of the dietary habits, focusing on the different intake of milk, dairy products, meat, sausages, ham, fish, eggs, legumes, cereals, fruit, vegetables, sugar, sweets, fats and alcohol.

Data analysis was performed comparing stone formers and controls, and after splicing the whole sample in three subgroups ( $<30$ years, 31-40 years, $>40$ years). In fact, analyzing the clinical history of the patients, it was clear that the subjects under 30 generally show more severe disease (Table 2).

Results were analyzed using suitable statistical tests: the frequencies were compared using the $\chi^{2}$ Fisher test, while the data of the bromatological decomposition were reported as mean \pm standard deviation (SD) and compared using Student T test (SPSS, Chicago, IL).

Agreement of Unique Ethical Committee of Province of Parma, Italy, was obtained.

\section{Results}

No differences in the main characteristics of stone formers and controls were found (Table 1).

Dividing stone formers into three age subgroups (under 30 years, 31-40 years, over 40 years), women under 30 showed a more severe disease (earlier age of onset, shorter recurrence interval, higher stone rate) (Table 2).

The analysis of food intake by bromatological separation of the three-day dietary diary showed that female stone formers have a calorie, carbohydrate, protein, sodium and magnesium intake significantly higher than the control group (Table 3). There were no differences in water, fat, fiber, potassium, calcium, oxalate, and phosphorus intake. Moreover, dividing the sample into three age subgroups (under 30 years, 31-40 years, over 40 years), also a lower intake of water $(950 \pm 500$ vs $1730 \pm 710 \mathrm{ml}, \mathrm{p}=0.0003$ ) and a higher intake of lipids $(83 \pm 34$ vs $70 \pm 22 \mathrm{ml}, \mathrm{p}=0.05)$ were found in the stone formers under 30 years.(Table 3 )

Using the food frequency tool, we also found that stone formers have a significantly higher consumption of sausages, ham, meat and sweets than the controls (Table 4, Additional file 2).

Finally, after dividing the sample into the three age subgroups, we found that the differences described above are amplified in the subjects under 30: in fact in female stone formers under 30 years we found a greater intake of sausages, ham and meat and a lower intake of fruit and vegetables, with high statistical significance (Table 5).

We also found that a significant percentage of women, even in the control group, have dietary habits that are consistently different than those recommended by INRAN (Table 4).

\section{Discussion}

The role of diet in the pathogenesis of idiopathic calcium nephrolithiasis has long been investigated. In spite of this, there is no wide consensus about which wrong dietary habits are critical in this process. Our findings seem to suggest that a high intake of calories, carbohydrates, proteins and salt are the main dietary factors associated with calcium nephrolithiasis in women. These findings overlap with those previously reported by Trinchieri et al [32], who also demonstrated that people with recurrent calcium nephrolithiasis have a higher dietary intake of purines and fats. However, those results were related to a mixed male-female cohort, and were

Table 2 Clinical course of the disease in relation with age-group.

\begin{tabular}{|c|c|c|c|}
\hline & \multicolumn{3}{|c|}{ Age groups } \\
\hline & $\begin{array}{c}<30 \text { years } \\
\text { (mean age } 24 \pm 5) \\
\text { n. } 29\end{array}$ & $\begin{array}{c}31-40 \text { years } \\
\text { (mean age } 37 \pm 3 \text { ) } \\
\text { n. } 38\end{array}$ & $\begin{array}{c}>41 \text { years } \\
(\text { mean age } 53 \pm 7) \\
\text { n. } 76\end{array}$ \\
\hline $\begin{array}{c}\text { STONE RATE } \\
\text { number of stones per patient per year\# }\end{array}$ & $1,2 \pm 1,2^{*}$ & $0,7 \pm 0,8$ & $0,4 \pm 0,5$ \\
\hline $\begin{array}{c}\text { AGE AT } 1^{\text {st }} \text { EPISODE } \\
\text { (years) }\end{array}$ & $21 \pm 6^{*}$ & $30 \pm 8$ & $42 \pm 15$ \\
\hline $\begin{array}{l}\text { INTERVAL BETWEEN 1ST AND 2ND EPISODE } \\
\text { (years) }\end{array}$ & $2,4 \pm 2,2^{*}$ & $5 \pm 5,8$ & $7,5 \pm 8,4$ \\
\hline
\end{tabular}

\footnotetext{
- Data are shown as mean \pm standard deviation.

${ }^{*}=p<0.01$ vs other groups.

\#Stone rate was calculated following the formula (total $n$. of stones $-n$. of stone at $1^{\text {st }}$ episode/time between $1^{\text {st }}$ and last episode).
} 
Table 3 Comparison between bromatologic decomposition (dietary intake) of the three-non-consecutive day dietary diaries of stone formers and healthy controls.

\begin{tabular}{|c|c|c|c|c|c|c|c|c|c|c|c|c|}
\hline & STONE FORMERS & CONTROLS (CTRL) $(\mathrm{N}=170)$ & $p$ & SF & CTRL & $\mathrm{p}$ & SF & CTRL & $\mathrm{p}$ & SF & CTRL & $p$ \\
\hline & & & & $<30$ ys & $<30$ ys & & $31-40$ ys & $31-40$ ys & & $>41$ ys & $>41$ ys & \\
\hline & & & & $(\mathrm{N}=29)$ & $(\mathrm{N}=33)$ & & $(\mathrm{N}=38)$ & $(\mathrm{N}=46)$ & & $(\mathrm{N}=76)$ & $(\mathrm{N}=91)$ & \\
\hline $\mathbf{H}_{\mathbf{2}} \mathbf{O}(\mathrm{ml})$ & $1970 \pm 679$ & $1942 \pm 685$ & 0,5 & $950 \pm 500$ & $1730 \pm 710$ & 0,0003 & $1998 \pm 582$ & $1915 \pm 445$ & 0.5 & $2034 \pm 592$ & $2006 \pm 561$ & 0.7 \\
\hline Caloric intake (Kcal) & $2116 \pm 1105$ & $1944 \pm 724$ & 0,004 & $2138 \pm 673$ & $1790 \pm 466$ & 0,01 & $2225 \pm 855$ & $1793 \pm 454$ & 0,01 & $2140 \pm 773$ & $1938 \pm 557$ & 0.02 \\
\hline Carbohydrates $(g)$ & $271 \pm 185$ & $241 \pm 92$ & 0,001 & $290 \pm 77$ & $252 \pm 71$ & 0.04 & $301 \pm 177$ & $220 \pm 61$ & 0.02 & $262 \pm 92$ & $240 \pm 69$ & 0.0006 \\
\hline Proteins $(g)$ & $79 \pm 35$ & $75 \pm 26$ & 0,04 & $85 \pm 26$ & $70 \pm 17$ & 0,005 & $82 \pm 26$ & $70 \pm 19$ & 0.03 & $79 \pm 18$ & $75 \pm 28$ & 0.05 \\
\hline Lipids $(g)$ & $82 \pm 54$ & $76 \pm 49$ & 0,07 & $83 \pm 34$ & $70 \pm 22$ & 0.05 & $83 \pm 19$ & $77 \pm 16$ & 0.2 & $80 \pm 43$ & $80 \pm 38$ & 0.9 \\
\hline Fibers $(g)$ & $15,6 \pm 11,5$ & $15,1 \pm 7,9$ & 0,4 & $12,1 \pm 5,4$ & $14,1 \pm 6,3$ & 0.2 & $15,7 \pm 9,9$ & $12,4 \pm 4,5$ & 0.09 & $16,5 \pm 7,2$ & $16,3 \pm 5,7$ & 0.9 \\
\hline Sodium (mg) & $2149 \pm 2394$ & $1683 \pm 1196$ & $<0,0001$ & $2551 \pm 2374$ & $1433 \pm 575$ & 0.004 & $2467 \pm 1640$ & $1729 \pm 1075$ & 0.04 & $2037 \pm 781$ & $1791 \pm 793$ & 0.05 \\
\hline Potassium (mg) & $2454 \pm 1085$ & $2421 \pm 914$ & 0,6 & $2181 \pm 764$ & $2208 \pm 668$ & 0.9 & $2499 \pm 742$ & $2239 \pm 556$ & 0.1 & $2529 \pm 878$ & $2596 \pm 672$ & 0.6 \\
\hline Calcium (mg) & $738 \pm 513$ & $728 \pm 429$ & 0,7 & $680 \pm 360$ & $717 \pm 271$ & 0.7 & $707 \pm 294$ & $682 \pm 221$ & 0.4 & $766 \pm 390$ & $742 \pm 332$ & 0.7 \\
\hline Oxalate (mg) & $141 \pm 209$ & $127 \pm 146$ & 0,2 & $126 \pm 94$ & $126 \pm 83$ & 0.7 & $126 \pm 70$ & $112 \pm 65$ & 0.2 & $155 \pm 182$ & $134 \pm 99$ & 0.4 \\
\hline Magnesium (mg) & $269 \pm 144$ & $247 \pm 119$ & 0,01 & $259 \pm 94$ & $218 \pm 63$ & 0.03 & $281 \pm 116$ & $235 \pm 64$ & 0.05 & $267 \pm 81$ & $260 \pm 88$ & 0.6 \\
\hline Phosphorus (mg) & $1049 \pm 435$ & $1013 \pm 416$ & 0,2 & $1007 \pm 411$ & $964 \pm 262$ & 0.6 & $1017 \pm 226$ & $963 \pm 324$ & 0.4 & $1067 \pm 324$ & $1045 \pm 315$ & 0.7 \\
\hline
\end{tabular}

Data are shown as daily mean \pm standard deviation. 
Table 5 Results from food frequency questionnaire in stone formers and controls under 30.

PERCENTAGE OF UNDER 30 WOMEN WITH INAPPROPRIATE INTAKE (VARIATIONS FROM RECOMMENDATIONS) OF VARIOUS NUTRIENTS ACCORDING TO INRAN GUIDELINES

\begin{tabular}{|c|c|c|c|}
\hline & $\begin{array}{c}\text { STONE } \\
\text { FORMERS } \\
<30 \text { ys } \\
\text { n. } 29\end{array}$ & $\begin{array}{l}\text { CONTROLS } \\
<30 \text { ys } \\
\text { n. } 39\end{array}$ & $p$ \\
\hline $\begin{array}{l}\text { SAUSAGES* } \\
\text { in excess (> } 3 \text { portions/week) }\end{array}$ & $41,2 \%$ & $7,7 \%$ & $\begin{array}{c}< \\
0,0001\end{array}$ \\
\hline $\begin{array}{l}\text { HAM§ } \\
\text { in excess (> } 3 \text { portions/week) }\end{array}$ & $35,3 \%$ & $10,3 \%$ & $\begin{array}{c}< \\
0,0001\end{array}$ \\
\hline $\begin{array}{l}\text { MEAT (excluding sausages and } \\
\text { ham) } \\
\text { in excess (> } 1 \text { portion/day) }\end{array}$ & $41,2 \%$ & $2,6 \%$ & $\begin{array}{c}< \\
0,0001\end{array}$ \\
\hline $\begin{array}{l}\text { FRUIT AND } \\
\text { VEGETABLES } \\
\text { Lacking }(<5 \text { portions/day) }\end{array}$ & $58,8 \%$ & $23,1 \%$ & $\begin{array}{c}< \\
0,0001\end{array}$ \\
\hline
\end{tabular}

The portions for each food are given in Additional file 2.

*Sausages: Italian Typical Foods (Salame, Coppa, Mortadella, Pancetta)

§Ham: Italian Typical Foods (Parma Ham, Baked Ham, Culatello, Fiocchetto, Spalla)

\#Sweets: cakes, biscuits, pastries, simple sugar, ice cream, toffees

not confirmed considering only the female part of the cohort. Moreover, a large number of older studies failed to demonstrate a positive correlation between carbohydrate and protein intake and idiopathic calcium nephrolithiasis [27-31], revealing in some cases a positive correlation with fat intake [27].

A more recent study by $\mathrm{Al}$ Zahrani et al [34] showed a positive correlation between calcium nephrolithiasis and calorie and carbohydrate intake, but not with

Table 4 Results from food frequency questionnaire in all stone formers and controls.

PERCENTAGE OF WOMEN WITH INAPPROPRIATE INTAKE (VARIATIONS

FROM RECOMMENDATIONS) OF VARIOUS NUTRIENTS ACCORDING TO INRAN GUIDELINES

\begin{tabular}{lccc}
\hline & $\begin{array}{c}\text { STONE } \\
\text { FORMERS } \\
\text { n. 143 }\end{array}$ & $\begin{array}{c}\text { CONTROLS } \\
\text { n. 170 }\end{array}$ & p \\
& $43,1 \%$ & $11,1 \%$ & $\begin{array}{c}< \\
\mathbf{0 , 0 0 0 1}\end{array}$ \\
\hline $\begin{array}{l}\text { SAUSAGES* } \\
\text { in excess (> 3 portions/week) }\end{array}$ & $29,4 \%$ & $13,9 \%$ & $<$ \\
\hline $\begin{array}{l}\text { HAM§ } \\
\text { in excess (> 3 portions/week) }\end{array}$ & $66,7 \%$ & $18,1 \%$ & $\mathbf{0 , 0 0 0 1}$ \\
\hline $\begin{array}{l}\text { SWEETS\# } \\
\text { in excess (> 1 portion/day) }\end{array}$ & $21,6 \%$ & $4,2 \%$ & $<$ \\
\hline $\begin{array}{l}\text { MEAT (excluding sausages and } \\
\text { ham) } \\
\text { in excess (> 1 portion/day) }\end{array}$ & & & $\mathbf{0 , 0 0 0 1}$ \\
\hline
\end{tabular}

The portions for each food are given in Additional file 2.

*Sausages: Italian Typical Foods (Salame, Coppa, Mortadella, Pancetta) §Ham: Italian Typical Foods (Parma Ham, Baked Ham, Culatello, Fiocchetto, Spalla)

\#Sweets: cakes, biscuits, pastries, simple sugar, ice cream, toffees protein intake. It also pointed out that stone formers have an excessive intake of dietary sodium, another element coherent with our findings. The relation between salt and nephrolithiasis has been studied and understood only in the last decade, and some interventional studies have demonstrated that lowering salt intake may lead to a reduced risk for kidney stone onset or recurrence [37-39].

We did not find differences in the intake of calcium between stone formers and controls. However, a low dietary intake of calcium is a well known risk factor for calcium nephrolithiasis, as it leads to an increase in oxalate intestinal absorption [20]. Some studies actually demonstrated that recurrent idiopathic calcium nephrolithiasis patients have a lower intake of calcium than healthy controls $[33,34]$. It is possible that nowadays stone recurrent patients are aware that a low-calcium diet is not suitable for their disease, and therefore do not limit the intake of milk and dairy products, as they did in the past. Also oxalate intake was not different in the two groups; however we could not estimate urinary oxalate which could be higher in stone formers: in fact carbohydrates, protein and salt intake was significantly higher in our stone formers group and it is well-known that an increased assumption of some sugars (i.e. lactose, sucrose, fructose, xylitol and sorbitol), some aminoacids (i.e. glycine, tyrosine, tryptophan, phenylalanine and hydroxyproline), and salt can augment the oxalate endogenous production and urinary oxalate excretion [25,38-42]. Unfortunately, we cannot estimate in our group dietary habits before stone appearance nor we can estimate what dietary advice the women studied have received before this study. Moreover, it is obvious that the risk of kidney stone recurrence is not determined by a single or by few dietary inbalances, but is a multi-factorial process determined by the sum of a large number of risk factors, all of whom are not necessarily present at the same time.

The role of diet in the pathogenesis of recurrent calcium nephrolithiasis is therefore outstanding. Indirect proof comes also from the perspective studies published in the last years [37-41,43]. These studies show that a change of dietary habits may decrease kidney stone occurrence. In particular, the limitation of salt and animal protein intake, with a normal intake of calcium, may adequately prevent kidney stones [37-41] but may not prevent stone recurrence [43].

Moreover, according to recent data, the salt, carbohydrate and protein excess and the deficiency of fruit and vegetables could increase the stone risk not only through a direct action on the urinary composition, but also through a systemic action, determining changes in the acid-base balance, particularly in the intracellular compartment; Frassetto et al [15] demonstrated that 
American diet induces a tonic baseline low-grade metabolic acidosis for an imbalance in the supply of nutrient precursors of bicarbonate and hydrogen ions, and kidney mitigates, but does not reduce to zero, the severity of this diet-induced acidemia and hypobicarbonatemia. Some studies confirm this hypothesis, by demonstrating that the urinary composition of stone formers and controls is not different for a large number of substances, even if there are wide differences in the nutrient intake [31]. Only urinary calcium is constantly higher in stone formers in all studies [3,31-34].

Hence, a diet rich in proteins, carbohydrates and sodium is also a diet with a high acid load because it leads to a decrease in the intake of the bicarbonate precursors (such as citrate). It also determines a low potassium intake and it increases the endogenous genesis of $\mathrm{H}$ + ions through energetic cycles (i.e. glycolisis, proteolysis, lipolysis). This exposes the body to a state of chronic low-grade acidosis. Therefore, there is an activation of homeostatic mechanisms, involving both the kidney and the body reserves of alkaline load, such as connective tissue and bone [44]. The buffering activity of bone, resulting from the activation of osteoclasts and the increase of the bone reabsorption, may contribute to explain the significant prevalence of hypercalciuria in stone formers compared to healthy controls [45]. This pathophysiological hypothesis seems also plausible in our patients.

A peculiarity of our research is the simultaneous use of two nutritional analysis tools in the same subjects: the bromatological food decomposition recorded by 3day diary and the food frequency questionnaire. This method has been reported in literature only once [31].

The food frequency questionnaire showed data that are coherent with the findings obtained through the 3day dietary diary: a high percentage of female stone formers has a consumption of sausages, ham, meat and sweets (foods rich in carbohydrates, proteins and salt) higher than that recommended in the INRAN guidelines. We must point out that the dietary differences between stone formers and controls seem much wider when recorded through the food frequency questionnaire than through the 3-day dietary diary. These findings suggest that the assessment of dietary habits over an extended period of time is a more sensitive tool than the methodical collection of dietary intake for a short period. In fact, while the dietary record by food diary has certainly some advantages, such as the precise determination of the quantities of every food consumed and the possibility of a bromatological decomposition, it also has consistent limits, such as the possible onset of Hawthorne effect (phenomenon in which the awareness of being under observation causes a change in a behaviour or habit), the short length of the record and the possibility of bias due to the software that determines the composition of different foods. This updated software is indeed influenced by the variations of dosage of the chemical system and of food processing. On the other hand, the record by food frequency, being retrospective and conducted on longer periods of time, provides a more precise picture of the real eating habits of the subject, even if it is less specific in determining the quantity of every food eaten [46]. Thus, we believe that using two different tools for recording eating habits is preferable to choosing one or another.

Our results also highlight a feature which is uncommon in literature: the main nutritional imbalances, and a more severe disease course as well (earlier age of onset, shorter recurrence interval, higher stone rate), are characteristic of women under 30 . These subjects seem to be more prone to develop nephrolithiasis, but they are also predisposed to suffer from hypertension, atherosclerosis, diabetes and metabolic syndrome, all chronic illnesses which are strongly influenced by unhealthy dietary habits.

The main surveys published in literature, even the prospective ones, followed patients and controls aged between 40 and 75 years old [7]. Within the limits of our little sample, the results we obtained in the younger cohort represent a stimulus to carry out research in this age group. Moreover, our findings represents the dietary habits of women in Northern Italy and they could not be extended to other countries; therefore the supposed pathogenic role of an imbalanced diet can be confirmed only by a broader and perspective research, together with an intervention study.

\section{Conclusions}

In this paper we showed that the dietary habits in women with recurrent idiopathic calcium nephrolithiasis are significantly different than those of healthy controls. These habits consist in a low fruit and vegetable intake and in a high intake of simple sugars, protein and salt. This nutritional imbalance is more evident in younger subjects and in patients with a more severe disease who showed moreover a lower fluid intake and a higher intake of fats. We hope that wide awareness campaigns will rise to reduce wrong dietary habits, that are well known risk factors not only for nephrolithiasis but also for other widespread disease such as diabetes, hypertension, metabolic syndrome and osteoporosis.

\section{Additional material}

Additional file 1: Facsimile of the food frequency questionnaire form used in our research.

Additional file 2: Standard portions in Italian Diet according to the INRAN guidelines. 


\section{Author details}

'Department of Clinical Sciences, University of Parma, Via A. Gramsci 14, 43126 Parma, Italy. ${ }^{2}$ Department of Medicine, Surgery and Dentistry, University of Milan, Milan, Italy. ${ }^{3}$ Nephrology Unit, S. Raffaele Hospital, Milan, Italy. ${ }^{4}$ Department of Internal Medicine and Medical Specialties, Renal Program, Columbus-Gemelli University Hospital, Catholic University, Rome, Italy. ${ }^{5}$ Geriatric Unit, Parma University Hospital, Parma, Italy. ${ }^{6}$ Department of Internal Medicine and Biomedical Sciences, University of Parma, Parma, Italy.

\section{Authors' contributions}

TM, LB, LS, GV and GG designed research; TM, AN, BP, FP and FA conducted research; AG, FL and AT analysed data; TM, AN, AT and MM wrote the paper; AN had primary responsibility for final content. All authors read and approved the final manuscript.

\section{Competing interests}

The authors declare that they have no competing interests.

Received: 15 November 2011 Accepted: 28 March 2012

Published: 28 March 2012

\section{References}

1. Taylor EN, Stampfer MJ, Curhan GC: Dietary factors and the risk of incident kidney stones in men: new insights after 14 years of follow up. J Am Soc Nephrol 2004, 15:3225-3232.

2. Taylor EN, Curhan GC: Diet and fluid prescription in stone disease. Kidney Int 2006, 70:835-839.

3. Hess B: Nutritional aspects of stone disease. Endocrinol Metab Clin N Am 2002, 31:1017-1030.

4. Siener R: Impact of dietary habits on stone incidence. Urol Res 2006, 34:131-133.

5. Saint-Elie DT, Patel PV, Healy KA, Solomon T, Pattaras JG, Qian J, Master VA, Ogan $\mathrm{K}$ : The impact of income and education on dietary habits in stone formers. J Urol 2010, 76:307-313.

6. Borghi L, Meschi T, Maggiore U, Prati B: Dietary therapy in idiopathic nephrolithiasis. Nutr Rev 2006, 64:301-312.

7. Robertson WG, Heyburn PJ, Peacock M, Hanes FA, Swaminathan R: The effect of high animal protein intake on the risk of calcium-stone formation in the urinary tract. Clin Sci 1979, 57:285-288.

8. Kerstetter JE, O'Brien $\mathrm{KO}$, Insogna K: Low protein intake: the impact on calcium and bone homeostasis in humans. J Nutr 2003, S1:855-861.

9. Nguyen QV, Kalin A, Drouve U, Casez JP, Jaeger P: Sensitivity to meat protein intake and hyperoxaluria in idiopathic calcium stone formers. Kidney Int 2001, 59:2273-2281.

10. Holl MG, Allen LH: Sucrose ingestion, insulin response and mineral metabolism in humans. J Nutr 1987, 117:1229-1233.

11. Garg A, Bonanome A, Grundy SM, Unger RH, Breslau NA, Pak CYC: Effect of dietary carbohydrates on metabolism of calcium and other minerals in normal subjects and patients with noninsulin-dependent diabetes mellitus. J Clin Endocrinol Metab 1990, 70:1007-1013.

12. Taylor EN, Stampfer MJ, Curhan GC: Obesity, weight gain, and the risk of kidney stones. Am Med Association 2005, 293:455-462.

13. Sakhaee K, Harvey JA, Padalino PK, Whitson P, Pak CYC: The potential role of salt abuse on the risk for kidney stone formation. J Urol 1993, 160:310-312.

14. Kok DJ, lestra JA, Doorenbos CJ, Papapoulos SE: The effects of dietary excesses in animal protein and in sodium on the composition and the crystallization kinetics of calcium oxalate monohydrate in urines of healthy men. J Clin Endocrinol Metab 1990, 71:861-867.

15. Frassetto LA, Curtis Morris RJ, Sellmeyer DE, Sebastian A: Adverse effects of sodium chloride on bone in the aging human population resulting from habitual consumption of typical American diets. J Nutr 2008, 138:419S-422S

16. Lemann J Jr, Pleuss JA, Gray RW: Increased dietary calcium intake reduces urinary oxalate excretion in healthy adults. In Urolithiasis. Edited by: Walker VR, Sutton RAL, Cameron ECB, Pak CYC, Robertson WG. New York and London: Plenum Press; 1989:435-438.

17. Martini LA, Heilberg IP: Stop dietary calcium restriction in kidney stoneforming patients. Nutr Rev 2002, 60:212-214.
18. Curhan GC, Willett WC, Knight EL, Stampfer MJ: Dietary factors and the risk of incident kidney stones in younger women. Arch Intern Med 2004, 164:885-891.

19. Meschi T, Maggiore U, Fiaccadori E, Schianchi T, Bosi S, Adorni G, Ridolo E, Guerra A, Allegri F, et al: The effect of fruits and vegetables on urinary stone risk factors. Kidney Int 2004, 66:2402-2410.

20. Curhan GC, Willett WC, Rimm EB, Stampfer MJ: A prospective study of dietary calcium and other nutrients and the risk of symptomatic kidney stones. N Engl J Med 1993, 328:833-838.

21. Taylor EN, Curhan GC: Determinants of 24-hour urinary oxalate excretion. Clin J Am Soc Nephrol 2008, 3:1453-1460.

22. Pak CYC, Skurla C, Harvey J: Graphic display of urinary risk factors for renal stone formation. J Urol 1985, 134:867-870

23. Guerra A, Allegri F, Meschi T, Adorni G, Prati B, Nouvenne A, Novarini A, Maggiore $U$, Fiaccadori $E$, Borghi L: Effects of urine diluition on quantity, size and aggregation of calcium oxalate crystals induced in vitro by an oxalate load. Clin Chem Lab Med 2005, 43:585-589.

24. Curhan GC, Willett WC, Speizer FE, Stampfer MJ: Beverage use and risk for kidney stones in women. Ann Intern Med 1998, 128:534-540.

25. Taylor EN, Curhan GC: Fructose consumption and the risk of kidney stones. Kidney Int 2008, 73:207-212.

26. Goodman JW, Asplin JR, Goldfarb DS: Effect of two sports drinks on urinary lithogenicity. Urol Res 2009, 37:41-46.

27. Griffith HM, O'Shea B, Kevany JP, McCormick JS: A control study of dietary factors in renal stone formation. Br J Urol 1981, 53(5):416-420.

28. Power C, Baker DJ, Nelson M, Winter PD: Diet and renal stones: a casecontrol study. Br J Urol 1984, 56(5):456-459.

29. Griffith HM, O'Shea B, Maguire M, Koegh B, Kevany JP: A case-control study of dietary intake of renal stone patients. II. Urine biochemistry and stone analysis. Urol Res 1986, 14(2):75-82.

30. Wasserstein AG, Stolley PD, Soper KA, Goldfarb S, Maislin G, Agus Z: Casecontrol study of risk factors for idiopathic calcium nephrolithiasis. Mineral Electrolyte Metab 1987, 13(2):85-95.

31. Fellstrom B, Danielson BG, Karlstrom B, Lithell H, Ljunghall S, Vessby B: Dietary habits in renal stone patients compared with healthy subjects. $\mathrm{Br}$ J Urol 1989, 63:575-580.

32. Trinchieri A, Mandressi A, Luongo $P$, Longo $G$, Pisani E: The influence of diet on urinary risk factors for stones in healthy subjects and idiopathic renal calcium stone formers. Br J Urol 1991, 67:230-236.

33. Leonetti $F$, Dussol B, Berthezene $P$, Thirion $X$, Berland $Y$ : Dietary and urinary risk factors for stones in indiopathic calcium stone formers compared with healthy subjects. Nephrol Dial Transplant 1998, 13:617-622.

34. Al Zahrani H, Norman RW, Thompson C, Weerasinge S: The dietary habits of idiopathic calcium stone-formers and normal control subjects. BJU Int 2000, 85:616-620.

35. Guidelines for a healthy Italian diet. Italian National Institute for Research on Food and Nutrition (Linee Guida per una sana alimentazione italiana. Istituto Nazionale di Ricerca per gli Alimenti e la Nutrizione). [http://www.inran.it/648/linee_guida.html], Visited on November 2nd 2011.

36. Committee G: 2003 European Society of Hypertension - European Society of Cardiology guidelines for the management of arterial hypertension. J Hypertens 2003, 21(6):1011-1053.

37. Taylor EN, Fung $\pi$, Curhan GC: DASH-style diet associates with reduced risk for kidney stones. J An Soc Nephrol 2009, 20:2253-2259.

38. Nouvenne A, Meschi T, Prati B, et al: Effect of a low-salt diet on idiopathic hypercalciuria in calcium-oxalate stone formers: a 3-mo randomized controlled trial. Am J Clin Nutr 2010, 91:565-570.

39. Borghi L, Schianchi T, Meschi T, et al: Comparison of two diets for the prevention of recurrent stones in idiopathic hypercalciuria. N Engl J Med 2002, 346(2):77-84

40. Siener R, Schade N, Nicolay C, Von Unruh GE, Hesse A: The efficacy of dietary intervention on urinary risk factors for stone formation in recurrent calcium oxalate stone patients. J Urol 2005, 173:1601-1605.

41. Nouvenne A, Meschi T, Guerra A, Allegri F, Prati B, Fiaccadori E, Maggiore U, Borghi $L$ : Diet to reduce mild hyperoxaluria in patients with idiopathic calcium oxalate stone formation: a pilot study. J Urol 2009, 73:725-730.

42. Jaeger Ph, Robertson WG: Role of dietary intake and intestinal absorption of oxalate in calcium stone formation. Nephron Physiol 2004, 98:64-71. 
43. Dussol B, lovanna C, Rotily M, Morange S, Leonetti F, Dupuy P, Vazi A, Saveanu A, Loundou A, Berland Y: A randomized trial of low-animalprotein or high-fiber diets for secondary prevention of calcium nephrolithiasis. Nephron Clin Pract 2008, 110:c185-c194.

44. Burkhardt $P$ : The effect of the alkali load of mineral water on bone metabolism: interventional studies. J Nutr 2008, 138:435S-437S.

45. Arnett TR: Extracellular pH regulates bone cell function. J Nutr 2008, 138:415S-418S

46. Prentice RL, Mossavar-Rahmani $Y$, Huang $Y$, Van Horn L, Beresford $S A$, Caan B, Tinker L, Schoeller D, Bingham S, Eaton CB, Thomson C, Johnson KC, Ockene J, Sarto G, Heiss G, Neuhouser ML: Evaluation and comparison of food records, recalls, and frequencies for energy and protein assessment by using recovery biomarkers. Am J Epidemiol 2011, 174:591-603.

doi:10.1186/1479-5876-10-63

Cite this article as: Meschi et al:: Dietary habits in women with

recurrent idiopathic calcium nephrolithiasis. Journal of Translational Medicine 2012 10:63.

\section{Submit your next manuscript to BioMed Central} and take full advantage of:

- Convenient online submission

- Thorough peer review

- No space constraints or color figure charges

- Immediate publication on acceptance

- Inclusion in PubMed, CAS, Scopus and Google Scholar

- Research which is freely available for redistribution

Submit your manuscript at www.biomedcentral.com/submit 